\title{
Studi Literatur Senyawa Aktif Antibakteri dari Ekstrak Daun Salam Koja (Murraya koenigii (Linn) Spreng)
}

\author{
Muhammad Khalid Anshari *, Bertha Rusdi \\ Prodi Farmasi, Fakultas Matematika dan Ilmu Pengetahuan Alam, \\ Universitas Islam Bandung, Indonesia. \\ *mhdkhalid38@gmail.com, bertharusdi78@gmail.com
}

\begin{abstract}
Koja bay leaves (Murraya koenigii (Linn) Spreng) which are widely found in Indonesia are scientifically proven to have antibacterial effects. In this study, a Systematic Literature Review was conducted on the antibacterial effect of bay leaf koja so that it is known that bay leaf extract has antibacterial activity against Gram positive and Gram negative bacteria, the value of Minimum Inhibition Concentratiton (MIC) against these bacteria and the antibacterial compounds contained therein. From the results of a search of 17 journals published in the last 10 years, it is known that koja bay leaf extract can inhibit Gram-positive bacteria among others Bacillus cereus, Bacillus megaterium, Bacillus subtilis, Staphylococcus aureus, Staphylococcus subfava, Staphylococcus epidermidis, Staphylococcus subfava, Streptococcus mutans, Lactobacillus acidophilus, Lactobacillus casie, and Gram-negative bacteria among others Alcaligenesfecalis, Escherichia coli, Klebsiella pneumoniae, Proteus vulgaris, Pseudomonas aeruginosa, Salmonella abony, dan Salmonella thyphi with MIC values between 0,090 to $175 \mathrm{mg} / \mathrm{mL}$. Bay leaf extracts that have antibacterial activity are extracts of water, ethanol, petroleum ether, hexane, chloroform, ethyl acetate, and methanol. Chemical compounds that have antibacterial activity in bay leaf extract include acetophenone, alkaloid, carbazole alkaloid, crystalline, girinimbine, iso mahanimbine, koenidine, koenimbine, koenine, mahanimbine, mahanimbicine, dan mahanine.
\end{abstract}

Keywords: Antibacterial, Bay leaf extract, MIC.

Abstrak. Daun salam koja (Murraya koenigii (Linn) Spreng) yang banyak ditemukan di Indonesia secara ilmiah terbukti memiliki efek antibakteri. Pada penelitian ini dilakukan Systematic Literature Review mengenai efek antibakteri dari daun salam koja sehingga diketahui ekstrak daun salam koja memiliki aktivitas antibakteri terhadap bakteri Gram positif dan Gram negatif, nilai Minimum Inhibition Concentration (MIC) terhadap bakteri tersebut, dan senyawa yang memiliki aktivitas antibakteri di dalam ekstrak daun salam koja. Dari hasil penelusuran terhadap 17 jurnal yang diterbitkan dalam kurun waktu 10 tahun terakhir menyatakan bahwa ekstrak daun salam koja dapat menghambat bakteri Gram positif antara lain Bacillus cereus, Bacillus megaterium, Bacillus subtilis, Staphylococcus aureus, Staphylococcus subfava, Staphylococcus epidermidis, Staphylococcus subfava, Streptococcus mutans, Lactobacillus acidophilus, Lactobacillus casie, dan dapat menghambat bakteri Gram negatif antara lain Alcaligenesfecalis, Escherichia coli, Klebsiella pneumoniae, Proteus vulgaris, Pseudomonas aeruginosa, Salmonella abony, dan Salmonella thyphi dengan nilai MIC yang diperoleh antara 0,090 hingga $175 \mathrm{mg} / \mathrm{mL}$. Ekstrak daun salam koja yang memiliki aktivitas antibakteri adalah ekstrak air, etanol, petroleum eter, heksana, kloroform, etil asetat, dan metanol. Senyawa kimia yang memiliki aktivitas antibakteri di dalam ekstrak daun salam koja meliputi acetophenone, carbazole alkaloid, crystalline, girinimbine, iso mahanimbine, koenidine, koenimbine, koenine, mahanimbine, mahanimbicine, dan mahanine.

Kata Kunci: Antibakteri, Ekstrak daun salam koja, MIC. 


\section{A. Pendahuluan}

Masalah penyakit yang disebabkan oleh bakteri di negara berkembang terutama Indonesia masih cukup tinggi. Obat antibiotik dapat mengobati dan mencegah terjadinya penyakit infeksi dari bakteri (6). Berkembangnya populasi bakteri yang resistensi terhadap antibiotik di Indonesia menjadi permasalahan serius. Obat-obat antibiotik yang biasa digunakan di RSUD Dr. Moewardi pada tahun 2012 seperti Amoxicillin, Tetrasiklin, Gentamisin, Siprofloksiasin, dan Sefotaksim mudah mengalami resistensi terhadap bakteri (18). Obat antibiotik terjadi resistensi terhadap bakteri disebabkan pasien yang tidak tepat dan jarang mengkonsumsi obat antibiotik yang sudah diresepkan oleh dokter. Berbagai upaya pencarian senyawa antibakteri baru dilakukan untuk mengatasi permasalahan resistensi bakteri menggunakan tumbuhan obat sebagai antibiotik alami. Salah satu tumbuhan obat sebagai antibiotik alami adalah salam koja atau kari (Murraya koenigii (Linn) Spreng) dari Famili Rutaceae terdapat di Aceh yang dikenal sebagai "Daun Temurui" sebagai bumbu penyedap dalam masakan $(13 ; 17 ; 19)$. Selain itu, masyarakat Aceh juga memanfaatkan tumbuhan salam koja untuk mengobati penyakit antiemetik, anti diare, obat demam, anti jamur, obat depresan, anti inflamasi, obat pegal-pegal, dan obat nyeri ginjal (24). Daun salam koja juga dimanfaatkan oleh masyarakat di Sumatera Barat untuk mengobati penyakit diare dan demam (15). Beberapa penelitian sudah membuktikan bahwa ekstrak daun salam koja memiliki efek antibakteri $(11 ; 16 ; 20$; $31 ; 33 ; 35)$.

Rumusan masalah berdasarkan uraian latar belakang adalah:

1. Ekstrak daun salam koja memiliki efek antibakteri terhadap bakteri apa saja berdasarkan studi literatur?

2. Berapa nilai Minimum Inhibition Concentration (MIC) yang diperoleh dari ekstrak daun salam koja berdasarkan studi literatur?

3. Senyawa apa saja di dalam ekstrak daun salam koja sebagai antibakteri berdasarkan studi literatur?

Tujuan dari penelitian literature review untuk mengetahui ekstrak daun salam koja dapat menghambat pertumbuhan bakteri, nilai MIC-nya, dan ekstrak daun salam koja mengandung senyawa aktif memiliki efek antibakteri.

Manfaat penelitian ini menjelaskan informasi ilmiah mengenai kandungan senyawa aktif antibakteri daun salam koja sebagai bahan obat tradisional dan sebagai cara alternatif untuk mengatasi resistensi antibiotik dalam pengobatan penyakit infeksi.

\section{B. Metodologi Penelitian}

Metodologi penelitian yang digunakan pada penelitian skripsi yakni literature review. Diawali dengan pencarian jurnal dengan cara mengakses Google Scholar yang diterbitkan dalam kurun waktu 2011-2021. Kata kunci yang dipakai dalam melakukan pencarian jurnal yakni "Antibacterial activity", "Murraya koenigii", "Antibakteri", dan "MIC Antibacterial Murraya koenigii". Kata kunci tersebut digunakan dengan cara masing-masing per kata atau dikombinasikan. Kemudian, melakukan pemilihan jurnal dari kata kunci yang sudah dicari dengan cara melihat abstrak dan isi jurnal secara lengkap berdasarkan kriteria yang sudah ditentukan. Setelah jurnal-jurnal diseleksi dan sesuai dengan kriteria yang sudah ditentukan maka akan diperoleh jurnal yang akan digunakan untuk studi literatur.

Tahap terakhir yakni dilakukan pengambilan data-data dari jurnal yang meliputi metode yang digunakan pada pengujian efek antibakteri, kelompok senyawa kimia yang memiliki aktivitas antibakteri dari daun salam koja, dan nilai diameter zona hambatnya.

\section{Hasil Penelitian dan Pembahasan}

Hasil rangkuman penelitian ini berdasarkan studi literatur dari 17 jurnal membuktikan adanya efek antibakteri dari ekstrak daun salam koja dengan menggunakan pelarut aqueous, etanol, etil asetat, heksana, kloroform, metanol, dan petroleum eter. Efek tersebut diuji secara in vitro dengan menggunakan metode difusi sumur agar, difusi cakram, difusi disk, dan menggunakan metode broth micro dilution untuk menentukan nilai Minimum Inhibition Concentration (MIC). 
Ekstrak daun salam koja menghasilkan minyak atsiri memiliki khasiat antibakteri terhadap bakteri Gram positif dan Gram negatif. Bakteri uji yang digunakan adalah 16 bakteri Gram positif meliputi Bacillus cereus, Bacillus megaterium, Bacillus subtilis, Enterococcus faecalis, Lactobacillus acidophillus, Lactobacillus casei, Staphylococcus aureus, Staphylococcus epidermidis, Staphylococcus faecalis, Staphylococcus subfava, Sarcina lutea, Streptococcus mutans, Streptococcus pyogenes, Streptococcus pneumoniae, Streptococcus sanguinis, dan Vanomycin-Resistant Enterococcus. Bakteri Gram negatif yang digunakan sebanyak 13 bakteri yakni Alcaligenesfecalis, Escherichia coli, Klebsiella oxytoca, Klebsiella pneumoniae, Pasteurella mukocida, Pseudomonas aeruginosa, Proteus vulgaris, Salmonella abony, Salmonella paratyphi, Salmonella thyphi, Vibrio mimicus, Vibrio parahemolyticus, dan Shigella dysenteriae. Aktivitas dari ekstrak daun salam koja (Murraya koenigii (Linn) Spreng) berdasarkan dari nilai Minimum Inhibition Concentration (MIC) dan diameter zona hambatnya sangat berpotensi terhadap bakteri Gram positif dibandingkan bakteri Gram negatif. Hal ini disebabkan adanya perbedaan dinding sel pada kedua jenis bakteri tersebut karena bakteri Gram negatif memiliki dinding sel kompleks terdiri dari mengandung peptidoglikan dan 3 komponen penting yakni lipoprotein, lipolisakarida, dan membran periplasma sedangkan bakteri Gram positif hanya memiliki peptidoglikan dan asam teikhoat (27).

Polisakarida yang terdapat di dalam dinding sel bakteri Gram positif merupakan polimer yang bersifat polar dan berfungsi sebagai transport ion positif sehingga dinding sel bakteri bersifat relatif polar dan komponen membran plasma terdiri dari sekitar 30\% atau lebih berat dari sel (12). Perbedaan dari lapisan membran luar menyelimuti peptidoglikan menyebabkan dinding sel bakteri Gram negatif mengandung banyak lipid dan mampu melindungi dari pengaruh lingkungan dan lisis peptidoglikan dinding sel, sehingga bakteri Gram negatif lebih sulit dilewati oleh ekstrak daripada bakteri Gram positif (39). Hasil pengujian aktivitas antibakteri menyatakan bahwa diameter zona hambat bervariasi terhadap bakteri uji karena adanya beberapa faktor-faktor yang berpengaruh antara lain nilai Minimum Inhibition Concentration (MIC), kandungan zat antibakteri, kecepatan difusi, sifat media agar yang digunakan, jumlah bakteri yang diinokulasi, kecepatan pertumbuhan bakteri, konsentrasi bahan kimia, dan kondisi saat melakukan inkubasi (23).

Ekstrak daun salam koja mengandung kelompok senyawa kimia sebagai antibakteri meliputi alkaloid, fenil propanoid, fenol, flavonoid, glikosida, monoterpenoid, polifenol, quinon, saponin, sesquiterpenoid, steroids, tanin, terpenoid, dan triterpenoid. Alkaloid mempunyai kemampuan sebagai antibakteri dengan cara mengganggu komponen penyusun sel bakteri agar lapisan dinding selnya tidak dapat terbentuk secara utuh hingga menyebabkan kematian sel bakteri tersebut (21). Senyawa flavonoid merupakan golongan senyawa polifenol yang bersifat sebagai antibakteri dalam menghambat pertumbuhan bakteri uji. Mekanisme kerja dari flavonoid sebagai antibakteri yakni menghambat sintesis asam nukleat sehingga dapat menghambat pembentukan DNA dan RNA bakteri sehingga menyebabkan terjadinya kerusakan permeabilitas dinding sel bakteri (38). Mekanisme kerja fenol sebagai antibakteri dengan cara mendenaturasi protein sel bakteri sehingga menghambat proses pembentukan dinding sel bakteri yang sedang mengalami proses pertumbuhan (29). Saponin memiliki aktivitas antibakteri dengan cara melakukan difusi melalui membran luar dari dinding sel bakteri dan mengikat membran sitoplasma agar mengganggu dan mengurangi kestabilan membran sitoplasma mengakibatkan sitoplasma keluar dari sel bakteri (1). Glikosida berpotensi sebagai kelompok senyawa antibakteri yang dihasilkan dari ekstrak daun salam koja dengan cara melakukan penetrasi di dalam dinding sel bakteri sehingga menyebabkan kerusakan dinding sel bakteri (2). Tanin merupakan golongan senyawa polifenol terbesar dalam tumbuhan yang memiliki aktivitas antibakteri dengan cara mengkerutkan dinding sel atau membran sel sehingga dapat mengganggu permeabilitas sel bakteri mengakibatkan menghambat pertumbuhan bakteri bahkan mengalami kematian (21).

Monoterpenoid, sesquiterpenoid, dan triterpenoid merupakan jenis dari terpenoid. Mekanisme kerja terpenoid sebagai antibakteri adalah bereaksi dengan protein trans membran pada membran luar dinding sel bakteri yang dapat membentuk ikatan polimer yang kuat sehingga dapat mengakibatkan rusaknya protein trans membran pada bakteri (5). Mekanisme 
kerja steroid sebagai antibakteri yakni merusak membran sel bakteri (26). Mekanisme kerja kelompok senyawa kuinon sebagai antibakteri dari ekstrak daun salam koja dengan cara membentuk senyawa kompleks yang bersifat irreversibel dengan residu asam amino nukleofilik pada protein trans membran pada membran plasma, polipeptida, dinding sel, dan enzim yang terdapat pada permukaan membran sel sehingga mengganggu pertumbuhan sel bakteri (2).

Tabel 1. Rangkuman Hasil Penelitian Efek Antibakteri dari Ekstrak Daun Salam Koja.

\begin{tabular}{|c|c|c|c|c|c|c|c|}
\hline No. & Pelarut & Bakteri Uji & $\begin{array}{l}\text { MIC } \\
(\mathrm{mg} / \mathrm{mL})\end{array}$ & $\begin{array}{l}\text { Diameter Hambat } \\
(\mathrm{mm})\end{array}$ & Metode Uji & $\begin{array}{l}\text { Senyawa } \\
\text { Antibakteri }\end{array}$ & Pustaka \\
\hline \multirow[t]{4}{*}{1.} & Kloroform & Enterococcus faecalis & - & $11,6(500 \mu \mathrm{g} / \mathrm{mL})$ & Metode uji difusi & Alkaloid, & Vijayanand et al., \\
\hline & & Klebsiella oxytoca & - & $9,6(500 \mu \mathrm{g} / \mathrm{mL})$ & sumur agar & glikosida, saponin, 2 & 2014 \\
\hline & & Escherichia coli & - & $6,0(500 \mu \mathrm{g} / \mathrm{mL})$ & & dan tanin & \\
\hline & & Staphylococcus aureus & - & $10(500 \mu \mathrm{g} / \mathrm{mL})$ & & & \\
\hline \multirow[t]{3}{*}{2.} & Etanol & Escherichia coli & - & $11(50 \mu \mathrm{L})$ & Metode uji difusi & Fenol dan & Neethu S. Kumar \\
\hline & & Pseudomonas aeruginosa & - & $15(100 \mu \mathrm{L})$ & agar & flavonoid & and Neethu \\
\hline & & & & & & & Simon, 2016 \\
\hline \multirow[t]{17}{*}{3.} & Metanol & Bacillus cereus & 1,25 & 9,22 & Metode uji difusi & Carbazole & Satish Chand \\
\hline & & Bacillus megaterium & 1,25 & 10,37 & cakram & alkaloid, & Saini and Dr. \\
\hline & & Bacillus subtilis & 0,312 & 14,39 & & monoterpenoid, & Manoj Kumar \\
\hline & & Staphylococcus aureus & 0,312 & 16,64 & & dan & Tyagi, 2015 \\
\hline & & Staphylococcus epidermidis & 0,625 & 12,29 & & sesquiterpenoid & \\
\hline & & Staphylococcus subfava & 0,625 & 9,33 & & & \\
\hline & & Alcaligenesfecalis & 2,50 & 5,55 & & & \\
\hline & & Escherichia coli & 2,50 & 8,05 & & & \\
\hline & & Klebsiella pneumoniae & 2,50 & 7,76 & & & \\
\hline & & Pseudomonas aeruginosa & 1,25 & 4,89 & & & \\
\hline & & Salmonella abony & 1,25 & 8,86 & & & \\
\hline & Aqueous & Bacillus cereus & 2,50 & 7,25 & & & \\
\hline & & Bacillus megaterium & 2,50 & 8,22 & & & \\
\hline & & Bacillus subtilis & 0,625 & 11,67 & & & \\
\hline & & Staphylococcus aureus & 0,625 & 12,09 & & & \\
\hline & & Staphylococcus epidermidis & 1,25 & 10,61 & & & \\
\hline & & Pseudomonas aeruginosa & 2,50 & 1,52 & & & \\
\hline \multirow[t]{18}{*}{4.} & Etanol & Pseudomonas aeruginosa & 25 & 8,33 & Metode difusi agar & Carbazole alkaloid & d Shruthi et al., \\
\hline & & Escherichia coli & 12,5 & 8,30 & dan micro-broth & & 2012 \\
\hline & & Staphylococcus aureus & 50 & 6,37 & dilution method & & \\
\hline & & Klebsiella pneumoniae & 12,5 & 12,43 & & & \\
\hline & & Salmonella thyphi & 12,5 & 9,23 & & & \\
\hline & Kloroform & Pseudomonas aeruginosa & 25 & 7,23 & & & \\
\hline & & Escherichia coli & 50 & 6,17 & & & \\
\hline & & Staphylococcus aureus & 50 & 6,23 & & & \\
\hline & & Klebsiella pneumoniae & 12,5 & 11,27 & & & \\
\hline & & Salmonella thyphi & 12,5 & 10,23 & & & \\
\hline & Petroleum & Pseudomonas aeruginosa & 50 & 5,17 & & & \\
\hline & eter & Escherichia coli & 25 & 5,17 & & & \\
\hline & & Staphylococcus aureus & 50 & 4,50 & & & \\
\hline & & Klebsiella pneumoniae & 25 & 8,23 & & & \\
\hline & & Salmonella thyphi & 50 & 12,13 & & & \\
\hline & Air & Pseudomonas aeruginosa & 25 & 4,43 & & & \\
\hline & & Escherichia coli & 12,5 & 7,47 & & & \\
\hline & & Staphylococcus aureus & 50 & 5,47 & & & \\
\hline
\end{tabular}


160 | Muhammad Khalid Anshari, et al.

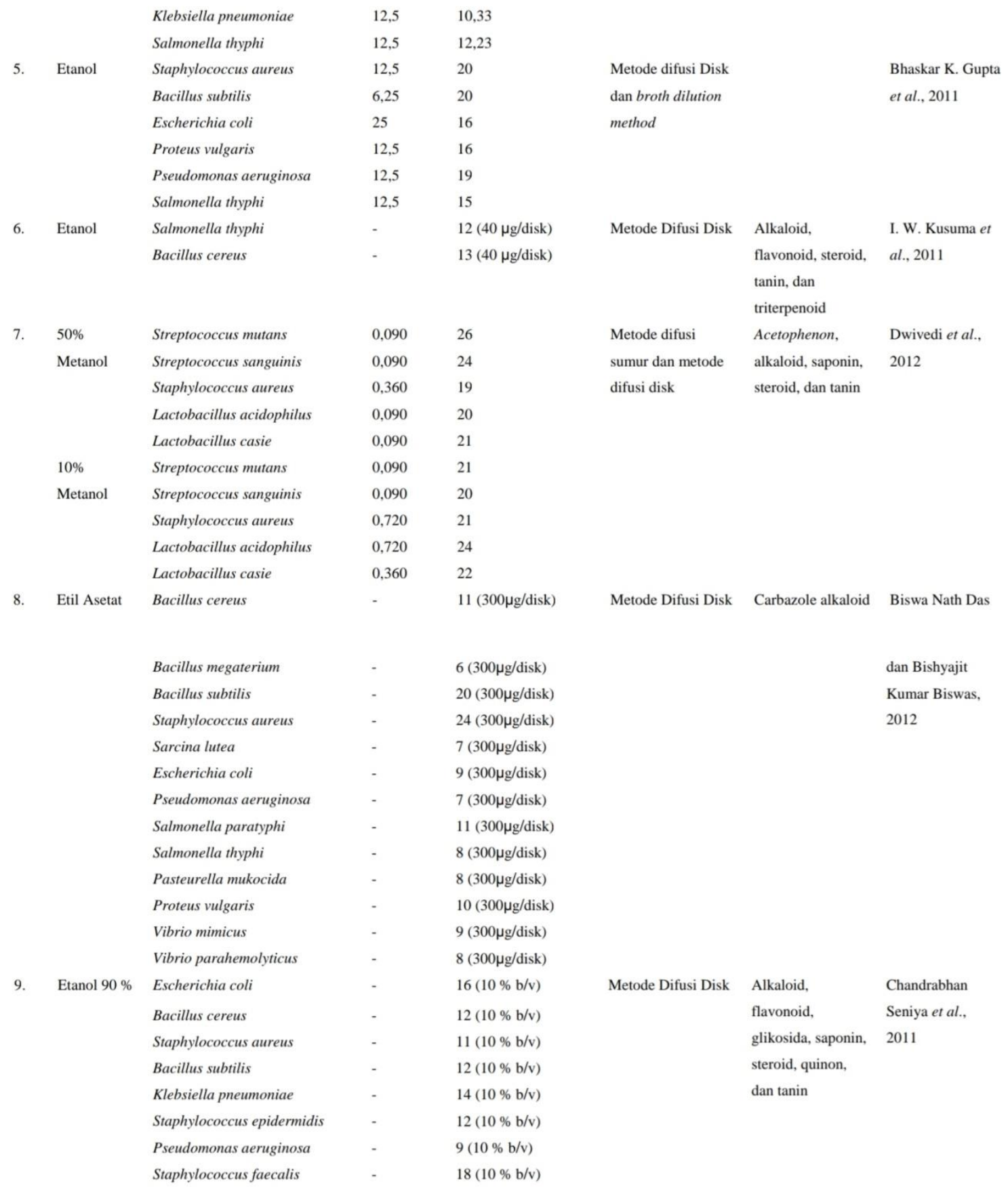




\begin{tabular}{|c|c|c|c|}
\hline \multirow[t]{10}{*}{ Etanol $70 \%$} & Escherichia coli & - & $12(10 \mathrm{sb} / \mathrm{v})$ \\
\hline & Bacilhus cereus & - & $16(10 \times \mathrm{h} / \mathrm{v})$ \\
\hline & Stuphylococcus aureus & - & $10(10 \leqslant \mathrm{~b} /$ \\
\hline & Bacillus subtilis & - & $14(10 \times \mathrm{b} / \mathrm{v})$ \\
\hline & Klebsiella pneumoniae & - & $12(10 \times \mathrm{b} / \mathrm{v})$ \\
\hline & Shaphylococcus epidermidis & - & $13(10 \times \mathrm{b} / \mathrm{v})$ \\
\hline & Psrudomonas aeruginosa & - & $10(10 \times \mathrm{b} / \mathrm{v})$ \\
\hline & Staphylococrus faecalis & - & $12(10 \times \mathrm{b} / \mathrm{v})$ \\
\hline & Vanomycin-resistant & - & $8(10 \mathrm{~s} \mathrm{b/v})$ \\
\hline & Enterococcus & & \\
\hline \multirow[t]{10}{*}{ Metanol } & Escherichia coli & - & $16(10 \times \mathrm{b} / \mathrm{v})$ \\
\hline & Bacillus cereus & - & $10(10 \times b / v)$ \\
\hline & Stuphylococcus aurrus & - & $14(10 \mathrm{sb} / \mathrm{v})$ \\
\hline & Bacillus subtilis & - & $10(10 \leqslant \mathrm{~b} / \mathrm{v})$ \\
\hline & Klebsiella pneumoniae & - & $9(10 \times b / v)$ \\
\hline & Stuphylococcus epidermidis & - & $8(10 \leqslant \mathrm{~b} / \mathrm{v})$ \\
\hline & Pseudomonas aenuginosa & - & $14(10 \% \mathrm{~b} / \mathrm{v})$ \\
\hline & Staphylococrus faecalis & - & $15(10 \times \mathrm{b} / \mathrm{v})$ \\
\hline & Vancomycin-resistant & - & $13(10 \% \mathrm{~b} / \mathrm{v})$ \\
\hline & Enterococcus & & \\
\hline \multirow[t]{10}{*}{ Kloroform } & Escherichia coli & - & $12(10 \leqslant \mathrm{~b} / \mathrm{v})$ \\
\hline & Bacillus cereus & - & $10(10 \times \mathrm{b} / \mathrm{v})$ \\
\hline & Staphylococcus aurreus & - & $13(10 \mathrm{~s} \mathrm{b/v})$ \\
\hline & Bacillus subtilis & - & $9(10 \leqslant b / v)$ \\
\hline & Klebsiella pmeumoniae & - & $12(10 \times \mathrm{b} / \mathrm{v})$ \\
\hline & Staphylococrus epidermidis & - & $14(10 \times \mathrm{b} / \mathrm{v})$ \\
\hline & Pseudomonas aeruginosa & - & $12(10 \times \mathrm{b} / \mathrm{v})$ \\
\hline & Staphylococrus faecalis & - & $13(10 \leqslant \mathrm{~b} / \mathrm{v})$ \\
\hline & Vancomycin-resistant & - & $10(10 \times \mathrm{b} / \mathrm{v})$ \\
\hline & Enterm & & \\
\hline
\end{tabular}

\begin{tabular}{|c|c|c|c|c|c|c|c|}
\hline 10. & Etanol & Staphylococcus aureus & - & $9,6(0,025 \mathrm{gram} / \mathrm{mL})$ & Metode Difusi Agar & $\begin{array}{l}\text { Flavonoid dan } \\
\text { tanin }\end{array}$ & $\begin{array}{l}\text { Unita and Colvin, } \\
2016\end{array}$ \\
\hline \multirow[t]{3}{*}{11.} & Etanol & Escherichia coli & - & $6,75(12,5 \% \mathrm{~b} / \mathrm{v})$ & Metode Difusi Agar & Alkaloid, fenol, & Rastina, dkk, \\
\hline & & Pseudomonas sp. & - & $7,10(12,5 \% \mathrm{~b} / \mathrm{v})$ & Cakram & flavonoid, dan & 2015 \\
\hline & & Staphylococcus aureus & - & $5,20(12,5 \% \mathrm{~b} / \mathrm{v})$ & & saponin & \\
\hline \multirow[t]{2}{*}{12.} & Minyak & Streptococcus pyogenes & - & $11.67(5 \% \mathrm{~b} / \mathrm{b})$ & Metode Difusi & Fenil propanoid & Agustin Rosa \\
\hline & Atsiri & Shigella dysenteriae & - & $9,33(10 \% \mathrm{~b} / \mathrm{b})$ & Cakram & dan terpenoid & Fadila et al., 2020 \\
\hline \multirow[t]{9}{*}{13.} & Etanol & Staphylococcus aureus & 12,5 & 16,33 & Metode difusi & Carbazol alkaloids & M. Kavitha, 2017 \\
\hline & & Escherichia coli & 25 & 11,83 & sumur agar dan & & \\
\hline & & Pseudomonas aeruginosa & 25 & 12,9 & metode broth micro & & \\
\hline & Heksana & Staphylococcus aureus & 12,5 & 15,5 & dilution & & \\
\hline & & Escherichia coli & 25 & 11,5 & & & \\
\hline & & Pseudomonas aeruginosa & 25 & 13,66 & & & \\
\hline & Kloroform & Staphylococcus aureus & 12,5 & 16,23 & & & \\
\hline & & Escherichia coli & 25 & 12,83 & & & \\
\hline & & Pseudomonas aeruginosa & 25 & 13,66 & & & \\
\hline \multirow[t]{3}{*}{14.} & Heksana & Escherichia coli & - & $6(50 \% \mathrm{~b} / \mathrm{v})$ & Metode Difusi & Alkaloid, & Mustanir, dkk, \\
\hline & & Staphylococcus aureus & $\cdot$ & $7(50 \% \mathrm{~b} / \mathrm{v})$ & Cakram & $\begin{array}{l}\text { flavonoid, steroid, } \\
\text { dan terpenoid }\end{array}$ & 2019 \\
\hline & Metanol & Escherichia coli & - & $7(50 \% \mathrm{~b} / \mathrm{v})$ & & & \\
\hline
\end{tabular}




\begin{tabular}{|c|c|c|c|c|c|c|c|}
\hline & & Staphylococcus aureus & - & $7(25 \% \mathrm{~b} / \mathrm{v})$ & & & \\
\hline & Etil Asetat & Escherichia coli & - & $7(25 \% \mathrm{~b} / \mathrm{v})$ & & & \\
\hline & & Staphylococcus aureus & - & $10(50 \% \mathrm{~b} / \mathrm{v})$ & & & \\
\hline 15. & Etanol 3 & Staphylococcus aureus & 25 & 18,5 & Metode difusi agar & Mahanine & Charles S. \\
\hline & & Pseudomonas aeruginosa & 25 & 18,5 & cakram dan two-fold & & Vairappan et al., \\
\hline & & Klebsiella pneumoniae & 50 & 14,5 & microdilution broth & & 2011 \\
\hline & & Escherichia coli & 75 & 12,5 & method & & \\
\hline & & Streptococcus pneumoniae & 12,5 & 18 & & & \\
\hline & Etanol 2 & Staphylococcus aureus & 25 & 16 & Metode difusi agar & Mahanimbicine & \\
\hline & & Pseudomonas aeruginosa & 50 & 12,5 & cakram dan two-fold & & \\
\hline & & Klebsiella pneumoniae & 50 & 18,5 & microdilution broth & & \\
\hline & & Escherichia coli & 25 & 14 & method & & \\
\hline & & Streptococcus pneumoniae & 25 & 11 & & & \\
\hline & & Staphylococcus aureus & 75 & 8,5 & Metode difusi agar & Mahanimbine & \\
\hline & & Pseudomonas aeruginosa & - & - & cakram dan two-fold & & \\
\hline & & Klebsiella pneumoniae & 125 & 10,5 & microdilution broth & & \\
\hline & & Escherichia coli & 150 & 10,5 & method & & \\
\hline & & Streptococcus pneumoniae & 175 & 8,0 & & & \\
\hline & Minyak & Staphylococcus aureus & 50 & 12,5 & Metode difusi agar & B-caryophyllene & \\
\hline & Atsiri & Pseudomonas aeruginosa & 25 & 16,5 & cakram dan two-fold & with & \\
\hline & & Klebsiella pneumoniae & 25 & 18,5 & microdilution broth & caryophyllene & \\
\hline & & Escherichia coli & 50 & 14,5 & method & oxide dan $a$ - & \\
\hline & & Streptococcus pneumoniae & 75 & 10,0 & & humulene & \\
\hline 16. & Metanol & Staphylococcus aureus & - & $7,4(0,2 \mathrm{mg} / \mu \mathrm{L})$ & Metode uji difusi & Alkaloid, & D. T. Abeysinghe \\
\hline & & Pseudomonas aeruginosa & - & $5,7(0,2 \mathrm{mg} / \mu \mathrm{L})$ & disk & flavonoid, & et al., 2021 \\
\hline & & Escherichia coli & - & $5,8(0,2 \mathrm{mg} / \mu \mathrm{L})$ & & $\begin{array}{l}\text { polifenol, dan } \\
\text { tanin }\end{array}$ & \\
\hline 17 & Etanol & Staphylococcus aureus & - & $8,33(12,5 \mathrm{mg} / \mathrm{mL})$ & Metode difusi kertas & Carbazole & Irfan et al., 2016 \\
\hline & & Streptococcus sp. & - & $8,67(12,5 \mathrm{mg} / \mathrm{mL})$ & cakram & alkaloid, & \\
\hline & & Escherichia coli & - & $6,33(12,5 \mathrm{mg} / \mathrm{mL})$ & & crystalline, & \\
\hline & Metanol & Staphylococcus aureus & - & $9(6,25 \mathrm{mg} / \mathrm{mL})$ & & girinimbin, & \\
\hline & & Streptococcus sp. & - & $7,67(12,5 \mathrm{mg} / \mathrm{mL})$ & & glikosida, iso- & \\
\hline & & Escherichia coli & - & $3,33(25 \mathrm{mg} / \mathrm{mL})$ & & mahanimbin, & \\
\hline & & Proteus sp. & - & $3,00(12,5 \mathrm{mg} / \mathrm{mL})$ & & $\begin{array}{l}\text { koenine, } \\
\text { koenidine, } \\
\text { koenimbine, dan } \\
\text { triterpenoid }\end{array}$ & \\
\hline
\end{tabular}

\section{Kesimpulan}

Efek antibakteri dari daun salam koja secara in-vitro dapat menghambat bakteri sebanyak 29 bakteri yakni Alcaligenesfecalis, Bacillus cereus, Bacillus megaterium, Corynebacterium diphteriae, Bacillus subtilis, Lactobacillus casei, Escherichia coli, Klebsiella oxytoca, Klebsiella pneumoniae, Lactobacillus acidophillus, Enterococcus faecalis, Pasteurella mukocida, Pseudomonas aeruginosa, Salmonella thyphi, Proteus vulgaris, Staphylococcus aureus, Salmonella paratyphi, Sarcina lutea, Staphylococcus epidermidis, Shigelladysenteriae, Streptococcus pyogenes, Staphylococcus subfava, Streptococcus pneumoniae, Salmonella abony, Vanomycin-Resistant Enterococcus, Vibrio mimicus, dan Vibrio parahemolyticus. Nilai MIC terhadap bakteri tersebut berada pada rentang 0,090 hingga $175 \mathrm{mg} / \mathrm{mL}$. Potensi antibakteri daun salam koja tertinggi adalah terhadap bakteri Streptococcus mutans, Streptococcus sanguinis, Lactobacillus acidophilus, dan Lactobacillus casie dengan nilai MIC $0,090 \mathrm{mg} / \mathrm{mLdari}$ ekstrak yang digunakan yakni ekstrak metanol.

Ekstrak daun salam koja yang memiliki efek antibakteri adalah ekstrak etil asetat, air, etanol, heksana, kloroform, petroleum eter, dan metanol. Ekstrak daun salam koja memiliki senyawa kimia sebagai antibakteri meliputi acetophenone, alkaloid, carbazole alkaloid, crystalline, girinimbine, iso mahanimbine, koenidine, koenimbine, koenine, mahanimbine, mahanimbicine, dan mahanine. 


\section{Daftar Pustaka}

[1] Akbar, M. R. V., Budiarti, L. Y., \& Edyson. (2016). Perbandingan Efektivitas antara Ekstrak Metanol Kulit Batang Kasturi dengan Ampisilin terhadap Staphylococcus aureus in Vitro. Jurnal Kedokteran. Vol. 12(1): 1-9.

[2] Amalia, Alfi, Irma, Sari \& Risa, Nursanty. (2017). Aktivitas Antibakteri Ekstrak Etil Asetat Daun Sembung (Blumea balsamifera (L.) DC.) terhadap Pertumbuhan Bakteri Methicillin Resistant Staphylococcus aureus (MRSA). Prosiding Seminar Nasional Biotik. Page 387391.

[3] Bhaskar, K., Gupta, Mukul, Tailang, Alkesh, K. Lokhande, Eman, A., Subhey, Narayan, P. Gavatia, \& Arnab, Sarkar. (2011). Antimicrobial Activity of Ethanolic Extracts of Murraya Koenigii by Disc Diffusion and Broth Dilution Method. Journal of Pharmacy Research. Vol. 4(4): 1023-1024.

[4] Biswas, Nath, Das, \& Bishyajit, Kumar Biswas. (2012). Antibacterial and Cytotoxic Activities of the Leaf Extract of Murraya Koenigii. International Journal of Life Sciences Biotechnology and Pharma Research. Vol. 1(3): 58-64.

[5] Budifaka, M. J. (2014). Profil Fitokimia Aktivitas Antibakteri Tanaman Obat di Sulawesi Tenggara terhadap Bakteri Salmonella typhi YCTC. [Skripsi]. Kendari: Universitas Halu Oleo.

[6] Bussmann, R. W., Glenn, A., \& Sharon, D. (2010). Antibacterial Activity of Medicinal Plants of Northern Peru - Can Traditional Applications Provide Leads for Modern. Science Indian Journal Tradit Knowl. Vol. 9(4): 742-53.

[7] Chand, Satish, Saini \& Manoj, Kumar, Tyagi. (2015). Studies about Murraya Koenigii (Quality Estimation and Antibacterial and Antifungal Properties). International Journal of Pharmaceutical Science Invention. Vol. 4(8): 19-24.

[8] Chandrabhan, Seniya, Hotam, S. Choudhary, Mohar, S. Argal, Sanjay, Kumar, Ravindra, M. Thakkar, \& Santosh, K. Verma. (2011). The efficacy of Murraya Koenigii Leaf Extract on some Bacterial and a Fungal Strain by Disc Diffusion Method. Journal of Chemical and Pharmaceutical Research. Vol. 3(5): 697-704.

[9] Charles, S. Vairappan, Thilahgavani, Nagappan, Perumal, Ramasamy, M. Effendy, Abdul, Wahid, \& Thirukanthan, Chandra, Segaran. (2011). Biological Activity of Carbazole Alkaloids and Essential Oil of Murraya Koenigii against Antibiotic Resistant Microbes and Cancer Cell Lines. Molecules Journal Article. Vol. 16: 9651-9664.

[10] D. T. Abeysinghe, K. A. H. Kumara, K. A. D. Kaushalya, U. G. Chandrika, \& D. D. D. H. Alwis. (2021). Phytochemical Screening Total Polyphenol, Flavonoid Content, In Vitro Antioxidant and Antibacterial Activities of Sri Lankan Varieties of Murraya Koenigii and Micromelum Minutum Leaves. Heliyon Research Article. Vol. 7(2021): 1-7.

[11] Das, A. K., Rajkumar, V., \& Dwivedi, D. K. (2011). Antioxidant Effect of Curry Leaf (Murraya koenigii) Powder on Quality of Ground and Cooked Goat Meat. International Food Research Journal. Vol. 18(2): 536-569. DOI: http://www.ifrj.upm.edu.my/volume-182011.html.

[12] Dewi, F. K. (2010). Aktivitas Antibakteri Ekstrak Etanol Buah Mengkudu (Morinda citrfolia, Linnaues) terhadap Bakteri Pembusuk Daging Segar. Skripsi. Universitas Sebelas Maret.

[13] Dheeraj et al. (2014). Murraya koenigii buah Etnobotani, Fitokimia, dan Farmakologi Ulasan. Jurnal Farmakognosi dam Fitokimia. Vol. 3(3): 109-119.

[14] Dwivedi, Deepak, Rakesh, K. Patidar \& Vinod, Singh. (2012). Antioxidant and Antibacterial Potential of Murraya Koenigii against Human Cariogenic Pathogens. International Journal of Pharmaceutical Sciences and Research. Vol. 3(9): 3399-3406.

[15] Edrizal., Eka, Desnita., Threicy, Annisa., \& Andam, Suri. (2018). Uji Aktivitas Ekstrak Daun Sicerek (Clausena Excavata Burm. F.) Terhadap Candida Albicans. Ensiklopedia of Journal. Lembaga Penelitian dan Penerbitan Hasil Penelitian Ensiklopedia. Vol. 1(1): 169173. DOI: http://jurnal.ensiklopediaku.org. 
[16] Erkan, N., Tao, Z., Rupangsinghe, H. P. V., Uysal, B., \& Oksal, B. (2012). Antibacterial Activities of Essential Oils Extracted from Leaves of Murraya koenigii by Solvent-Free Microwave Extraction and Hydro-Distillation. Natural Product Communication. Vol. 7(1): 121-124. DOI: http://doi/pdf/10.1177/1934578X1200700139.

[17] Fachraniah., Kurniasih, E., \& Novilasari, D. T. (2012). Antioksidan dari Daun Kari. Jurnal Reaksi (Journal of Science and Technology). Vol. 10(21): 35-44. DOI: http://jurnal.pnl.ac.id/?p=1256.

[18] Hasanah, Uswatun. (2018). Uji Aktivitas Antibakteri Kombinasi Ekstrak Etanol 96\% Rimpang Kunyit Putih (Curcuma longa L.) dan Pare (Momordica charantia L.) Terhadap Bakteri Staphylococcus aureus dan Escherichia coli. [Skripsi]. Jurusan Kimia, Fakultas Sains Dan Teknologi, Universitas Islam Negeri Maulana Malik Ibrahim, Malang.

[19] Hermawan, I. (2015). Daya Saing Rempah Indonesia di Pasar Asean Periode Pra dan Pasca Krisis Ekonomi Global. Buletin Ilmiah Litbang Perdagangan. Vol. 3(2): 153-178. DOI: http://doi.org/10.30908/bilp.v9i2.6.

[20] Hidayanti, N., Yusro, F., \& Mariani, Y. (2020). Bioaktivitas Minyak Daun Kari Murraya koenigii L. Spreng Terhadap Bakteri Enterococcus faecalis dan Salmonella Typhimurium. Jurnal Biologi Makassar. Vol. 5(1): 95-102.

[21] Ibrahim, Arsyi \& Hadi, Kumoro. (2012). Identifikasi Metabolit Sekunder Dan Aktivitas Anti-Bakteri Ekstrak Daun Sungkai (Peronema canescens Jack.) Terhadap Beberapa Bakteri Patogen. Journal Trop. Pharm. Chem. Vol. 1(4): 8-18.

[22] Irfan, Uma, M. Hanan, Al Harbi \& Sarah, Ali. (2016). The Antibacterial Effect of Curry Leaves (Murraya Koenigii). European Journal of Pharmaceutical and Medical Research. Vol. 3(10): 382-387.

[23] Irianto, K. (2007). Menguak Dunia Mikroorganisme. Bandung: CV. Yrama Widya.

[24] Jain, V., Momin, M., \& Laddha, K. (2012). Murraya koenigii: An updated Review. International Journal of Ayurvedic and Herbal Medicine. Vol. 2(4): 607-627.

[25] Kavitha, M. (2017). Antibacterial and Antioxidant Activity of Leaf Organic Extracts of Local Cultivars of Murraya Koenigii (L.) Spreng from Tamilnadu. Bioscience Biotechnology Research Communications. Vol. 10(2): 359-364.

[26] Monalisa, D. T., Handayani., Sukmawati, D. (2011). Uji Daya Antibakteri Ekstrak Daun Tapak Liman (Elephantopus sacher L.) terhadap Staphylococcus aureus dan Salmonella thyphi. Jurnal Biomia. Vol. 9(2): 13-20.

[27] Mustanir., Tara, Rizki, Al-Qarana., Hilda, Gusvianna., \& Nurdin, Saidi. (2019). Analisa Potensi Ekstrak Daun Kari (Murraya koenigii L. Spreng). TALENTA Conference Series: Science \& Technology (ST). Vol. 2(1): 1-8. DOI: http://doi.org/10.32734/st.v2il.300.

[28] Neethu, S. Kumar, \& Neethu, Simon. (2016). Invitro Antimicrobial Activity and Phytochemical Analysis of Murraya Koenigii (L) Leaf Extracts. Global Journal of Science Frontier Research : C Biological Science. Vol. 16(1): 1-5.

[29] Pelczar, M. J. (2010). Dasar-dasar Mikrobiologi. Jakarta: UI Press

[30] Rastina, Mirnawati, Sudarwanto \& Ietje, Wientarsih. (2015). Aktivitas Antibakteri Ekstrak Etanol Daun Kari (Murraya Koenigii) terhadap Staphylococcus aureus, Escherichia coli, dan Pseudomonas sp. Jurnal Kedokteran Hewan. Vol. 9(2):185-188.

[31] Rajendran, M. P., Pallaiyan, B. B., \& Selvaraj, N. (2014). Chemical Composition Antibacterial and Antioxidant Profile of Essential Oil from Murraya koenigii (L.) Leaves. Avicenna Journal Phytomed. Vol. 4(3): 200-214. DOI: http://www.ncbi.nlm.nih.gov/pmc/articles/PMC4104627/pdf/AJP-4-200.pdf.

[32] Rosa, Agustin, Fadila Yeni, Mariani, \& Fathul, Yusro. (2020). Minyak Atsiri Daun Kari (Murraya koenigii (L.) Spreng) sebagai Penghambat Pertumbuhan Bakteri Streptococcus Pyogenes dan Shigella Dysenteriae. Jurnal Biologi Tropis. Vol. 20(2): 155-160.

[33] Selvamani, S., \& Balamurugan, S. (2014). Evaluation of the Antimicrobial Potential of Various Solvent Extracts of Murraya koenigii (Linn.) Spreng Leaves. International Journal 
Current Microbiology App. Sci. Vol. 3(9): 74-77.

[34] Shruthi, S. D., Harish, K., Handral, \& Hoti, S., L. (2012). In Vitro Evaluation of Antimicrobial Activities of Cruide Extracts from Murraya Koenigii Against Pathogenic Bacteria. International Journal of Pharmacy and Pharmaceutical Sciences. Vol. 4(4): 74-76.

[35] Unita, L., \& Voon, C. (2018). Daya Hambat Ekstrak Daun Kari Terhadap Pertumbuhan Bakteri Staphylococcus aureus. Jurnal Ilmiah PANNMED (Pharmacist, Analyst, Nurse, Nutrition, Midwivery, Environment, Dentist). Vol. 10(3): 287-291. DOI: http://doi.org/10.36911/pannmed.v10i3.117.

[36] Vijayanand, S., \& E. G. Wesely. (2014). Antimicrobial and Antioxidant Activity of Melia Azadirachta and Murraya koenigii. International Journal of Pharma Sciences and Research. Vol. 5(1): 1022-1027.

[37] Wijaya, Irawan, Kusuma, Harlinda, Kuspradini, Enos, Tangke, Arung, Farida, Aryani, YuHong Min, Jin-Sook Kim, \& Yong-ung Kim. (2011). Biological Activity and Phytochemical Analysis of Three Indonesian Medicinal Plants, Murraya Koenigii, Syzgium polyanthum, and Zingiber Purpurea. Journal Acupunct Meridian Stud. Vol. 4(1): 75-79.

[38] Xie, Y., Yang, W., Tang, F., Chen, X., \& Ren, L. (2015). Antibacterial Activities of Flavonoids: Structure-Activity and Mechanism. Current Medical Chemistry. Vol. 22(1): 132-149.

[39] Yusman, D. A. (2006). Hubungan Antara Aktivitas Antibakteri Kitosan dan Ciri Permukaan Dinding Sel Bakteri. Skripsi. Fakultas Matematika dan Ilmu Pengetahuan Alam. Institut Pertanian Bogor. 